\title{
Methodology for Assessing the Influence of Cultural Infrastructure on Regional Development in Poland and Ukraine
}

\author{
Alona Revko \\ Ph.D., Associate Professor of Social Work Department \\ Chernihiv National University of Technology, Chernihiv, Ukraine \\ e-mail: alohaha19@gmail.com
}

\section{Mykola Butko}

Ph.D., Professor, Head of the Department of Management and the Civil Service

Chernihiv National University of Technology, Chernihiv, Ukraine

e-mail: butko.mykola@yandex.ua

\section{Olha Popelo}

Ph.D., Associate Professor of the Department of Management and the Civil

Service, Chernihiv National University of Technology, Chernihiv, Ukraine

e-mail: popelo.olha@gmail.com

\begin{abstract}
The aim of the article is to characterize the level of the region's diversification according to the cultural component of social infrastructure based on grouped statistical indicators. This paper uses Perkal's synthetic ratio method to characterize the level of cultural infrastructure development in Ukrainian and Polish regions. The analysis, conducted between 2010 and 2017, concerned cultural organizations such as libraries, theaters, concert organizations, museums, cinemas, art and sports schools, and was based on regional data of Polish and Ukrainian public statistics. It was found that the primary barriers to access to cultural infrastructure are inadequate funding, disability, geographic remoteness, disparities in education, and material living conditions. The determinants of modernizing cultural infrastructure in the region are defined.
\end{abstract}

Keywords: social infrastructure, cultural infrastructure, human development, regional development

JEL: R1, O15, Z1 


\section{Introduction}

In the recent economic crisis and the new demands of the $21^{\text {st }}$ century, the basis for developing social infrastructure is a strong and comprehensive regional policy. This policy is aimed at building local partnerships, increasing human development and providing equal access, regardless of gender, to social infrastructure services (Revko 2017, p. 30). One of the main components of social infrastructure that influences human development is cultural infrastructure, which is characterized by the state of cultural development in the country, people's mentality and views, and the cultural integration of different groups. In social matters, culture can play a role in creating and maintaining the identity of the local community, its creativity, vitality, and internal cohesion.

The literature of the subject uses two meanings of cultural infrastructure: "hard," or capital cultural infrastructure, and "soft," or revenue cultural infrastructure. "Hard" involves long-term investment in facilities of cultural infrastructure, such as libraries, theaters, concert organizations, museums, cinemas, and art and sports schools, while "soft" refers to investment in information, knowledge networks, outreach programs, education, and audience development. Subsequently, these types of investment in cultural infrastructure have different temporalities: "hard" capital investments can occur relatively rapidly, are extremely visible and easily evaluated, while "soft" revenue investments occur over long periods, represent a process of performer and audience development, are relatively invisible, and are difficult to evaluate (Bryson 2007, p. 101).

It is important to note that cultural organizations constitute key elements in cultural infrastructure. For example, art schools, museums, theatres, and concert organizations play a crucial role in creating or supporting cultural infrastructures of everyday life because historically, art has played an important role in national identity-building and creating the social-humanitarian space of the region. Institutions of cultural infrastructure educate, train, and prepare people for higher levels of modern civilization (Gökçe Sanul \& Bas van Heur 2018, p. 805). The cultural infrastructure transmits identities and heritages, provides the materials for imagination and innovation, and educates people to participate as creative citizens (Bawden 2002, p. 25).

It is essential to keep in mind that the probability of cultural consumption declines with the increasing spatial distance between a potential consumer and the cultural institution. Thus, the regional level is clearly closer to the actual action space than the national level. Furthermore, a regional comparison of cultural infrastructure development is more informative and more suited to capturing causal mechanisms (Rössel and Weingartner 2016, p. 370).

The goal of this article is to characterize the level of the region's diversification according to the cultural component of social infrastructure based on grouped statistical indicators. Thus, the ranking of Polish voivodships and Ukrainian oblasts will be determined in terms of the level of cultural infrastructure development.

New regionalism is increasingly developing the local economy and social and cultural identities, and it is not completely subservient to the dictates of the cen- 
tral state. Moreover, the competitive position of the region is now partially founded on developing cultural infrastructure and concentrations of creativity and expertise (Bryson 2007, p. 104). In the context of the current process of decentralizing public administration, the modernization of cultural infrastructure plays a crucial role in building strong and inclusive local communities, and creating and reproducing creative and active generation. Richard Florida, for example, argues that investment in cultural infrastructure underpins regional competitiveness and requires an increase in spending from both the private and public sectors in the arts, culture, and all forms of innovation and creativity (Florida 2005, p. 77).

\section{Trends of cultural infrastructure development in Poland and Ukraine}

The degree of satisfaction of cultural needs is influenced by many factors: the degree of economic development of the region, the quantity and availability of cultural institutions, as well as the existing demand for cultural goods and services. The dynamics of the number of cultural infrastructure institutions in Ukraine is presented in Table 1. There was a negative trend in the number of Ukrainian cultural institutions between 2005 and 2017. There is a significant (20\%) decrease in the number of libraries from 19,800 units in 2005 to 16,800 units in 2017. Meanwhile, compared to 2005, in 2017, the number of clubs had decreased by $11 \%$ or by 2000 units.

Table 1. Dynamics of cultural infrastructure institutions in Ukraine, 2005-2017

\begin{tabular}{|l|r|r|r|r|r|}
\hline & 2005 & 2010 & 2015 & 2016 & 2017 \\
\hline Number of libraries, thousand units & 19.8 & 18.6 & 17.3 & 17.0 & 16.8 \\
\hline Number of clubs and sections, thousand units & 19.1 & 17.9 & 17.2 & 17.1 & 17.1 \\
\hline Number of theaters, units & 135 & 128 & 113 & 112 & 113 \\
\hline Number of concert organizations, units & 78 & 76 & 73 & 76 & 76 \\
\hline Number of museums, units & 437 & 511 & 564 & 576 & 574 \\
\hline Number of art schools, units & 1472 & 1399 & 1295 & 1296 & 1302 \\
\hline Number of sports schools, units & - & 1648 & 1397 & 1327 & 1315 \\
\hline Number of cinemas, units & 3300 & 2196 & 1118 & - & - \\
\hline
\end{tabular}

Source: authors' own elaboration based on data provided by the State Statistics Service of Ukraine: http://ukrstat.gov.ua. (accessed: 25.07.2019)

The dynamics of the number of cultural infrastructure institutions in Poland are presented in Table 2. Unlike in Ukraine, the number of Polish cultural institutions grew between 2005 and 2017. There is an increase in the number of almost all cultural infrastructure institutions. 
Alona Revko, Mykola Butko, Olha Popelo

Table 2. Dynamics of Polish cultural infrastructure institutions, 2005-2017

\begin{tabular}{|l|c|c|r|r|r|}
\hline & 2005 & 2010 & 2015 & 2016 & 2017 \\
\hline Number of libraries, thousand units & 8.6 & 8.3 & 9.7 & 9.6 & 9.5 \\
\hline Number of clubs and sections, thousand units & 3.9 & - & 4.1 & 4.2 & 4.2 \\
\hline Number of theaters, units & - & 183 & 177 & 182 & 187 \\
\hline Number of concert organizations, units & - & 41 & 41 & 41 & 43 \\
\hline Number of museums, units & 690 & 782 & 926 & 945 & 949 \\
\hline Number of art schools, units & 521 & 456 & 490 & 490 & 497 \\
\hline Number of sports schools, units & 9888 & 13,278 & - & 14,009 & 14,858 \\
\hline Number of cinemas, units & 536 & 438 & 444 & 484 & 491 \\
\hline
\end{tabular}

Source: authors' own elaboration based on (Kultura... 2018, pp. 78-81)

In particular, the number of sports schools increased by almost $50 \%$. However, the situation is worse for art schools, which decreased from 521 in 2005 to 497 in 2017 (i.e., less than $5 \%$ ).

It is important to note that libraries play an important role in regional development. They support community improvement by providing programming that addresses the health, education, and workforce development needs of local residents. Libraries offer a calm, quiet, neutral space, where anyone can access information for work or leisure. They provide learning and information resources for individuals, families, businesses, and nonprofit organizations (Public Libraries... 2014, p. 35).

Figure 1 below shows that Opolskie (35), Podkarpackie 34) and Lubelskie (32) voivodships have more libraries per 100,000 inhabitants. The number of readers per 100 inhabitants ranged from 15 in the Kujawsko-pomorskie, Podlaskie, and Swietokrzyskie voivodships to more than 20 per 100 inhabitants in Malopolskie (27), Mazowieckie (22), Dolnoslaskie (21) and Lubelskie (21) voivodships.

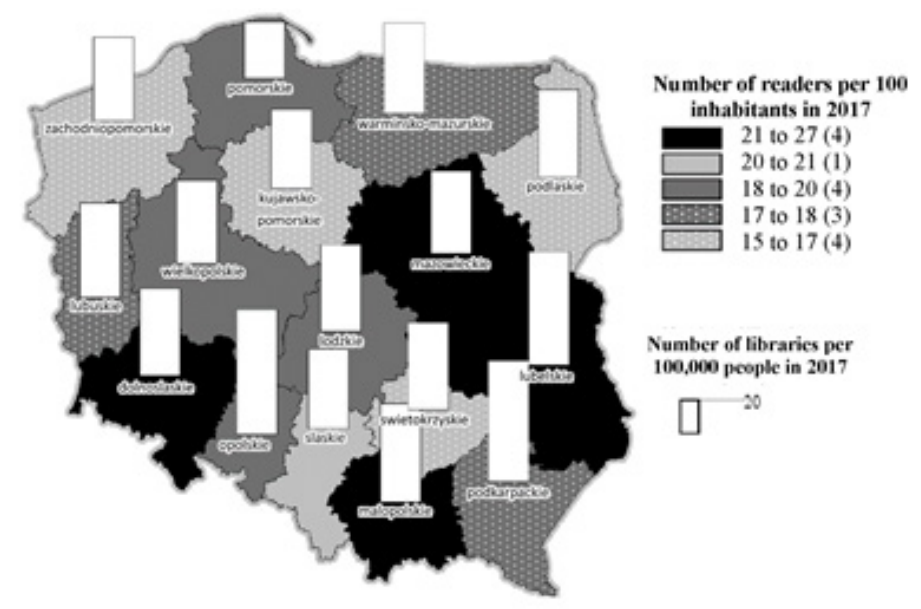

Figure 1. Number of readers and libraries in Poland in 2017

Source: authors' own elaboration based on the data provided by the Local Data Bank of Poland http://bdl.stat.gov.pl (accessed: 25.07.2019). 
In Ukraine, the situation is better in this aspect (Fig. 2).

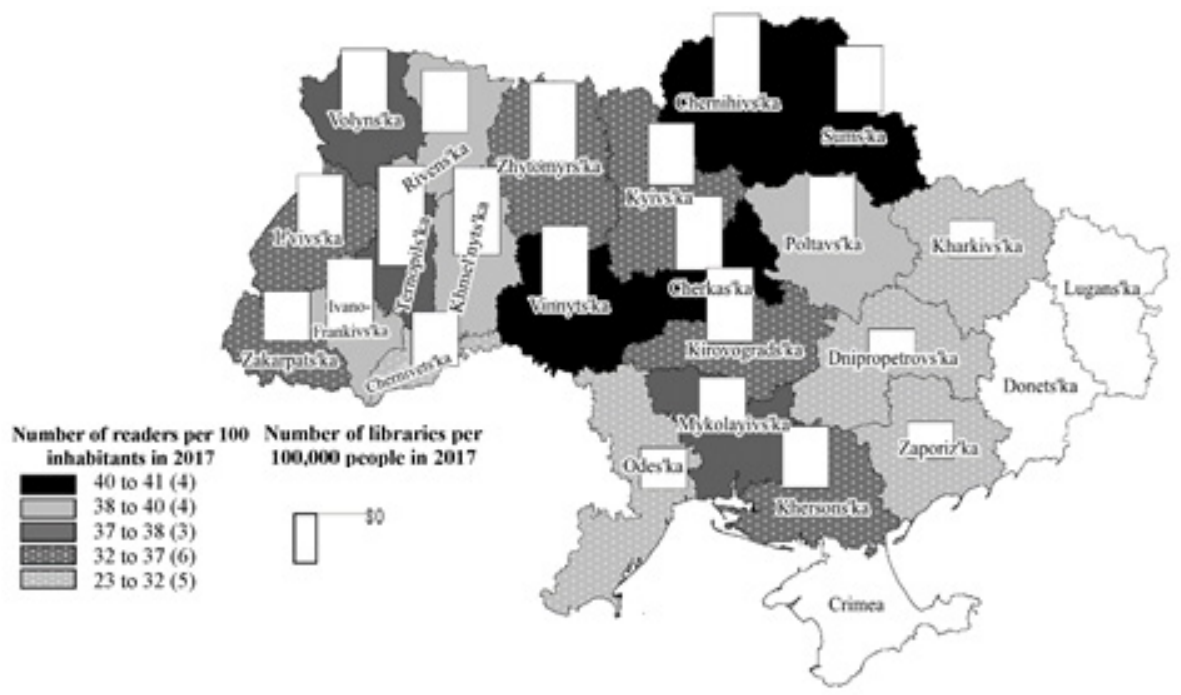

Figure 2. Number of readers and libraries in Ukraine in 2017

Source: authors' own elaboration based on the data provided by the State Statistics Service of Ukraine http://ukrstat.gov.ua (accessed: 25.07.2019).

The number of readers ranged from 23 per 100 inhabitants in the Kharkivs'ka (23), Odes'ka (24), Zaporiz'ka (24) oblasts to more than 40 per 100 inhabitants in Cherkas'ka (41), Sums'ka (41) and Vinnyts'ka (41) oblasts, i.e., twice as many as in Poland. At the same time, Ternopils'ka (81), Chernihivs'ka (71), and Khmel'nyts'ka (69) oblasts of Ukraine, according to the data for 2017, clearly outperform the remaining eighteen regions in the indicator of the number of libraries per 100,000 people. The worst situation takes place in Dnipropetrovs'ka (24), Kharkivs'ka (30), Zaporiz'ka (32), Odes'ka (34) and Zakarpats'ka (39) oblasts, where are less than 40 libraries per 100,000 people.

Figure 3 indicates the significant difference between Ukrainian oblasts regarding the number of museum visitors per 100 inhabitants.

The number of museum visitors in Ukraine per 100 inhabitants in 2017 ranged from 10 people per 100 inhabitants in Khersons'ka (10), Volyns'ka (22), Rivens'ka (22), Dnipropetrovs'ka (22), and Sums'ka (23) oblasts to 90 in Chernihivs'ka (90), L'vivs'ka (76), Cherkas'ka (68), and Zakarpats'ka (55).

During the seven years before 2017 (the last period for which data is publically available) the number of museum visitors fell in 9 oblasts from between $0.2 \%$ to $6.1 \%$ (Khmel'nyts'ka - 6.1\%; Kharkivs'ka - 3.7\%; Odes'ka - 2.6\%; Kirovograds'ka - 2.6\%; Rivens'ka - 2.3\%; Khersons'ka - 2\%; Zaporiz'ka - 1.5\%; Chernihivs'ka - 0.7\% and Poltavs'ka $-0.2 \%)$. At the same time, the number of museum visitors per 100 inhabitants rose in all voivodships in Poland from between 2.9\% (in Slaskie voivodship) to $13.5 \%$ (in Mazowieckie voivodship) (See Fig. 4). 


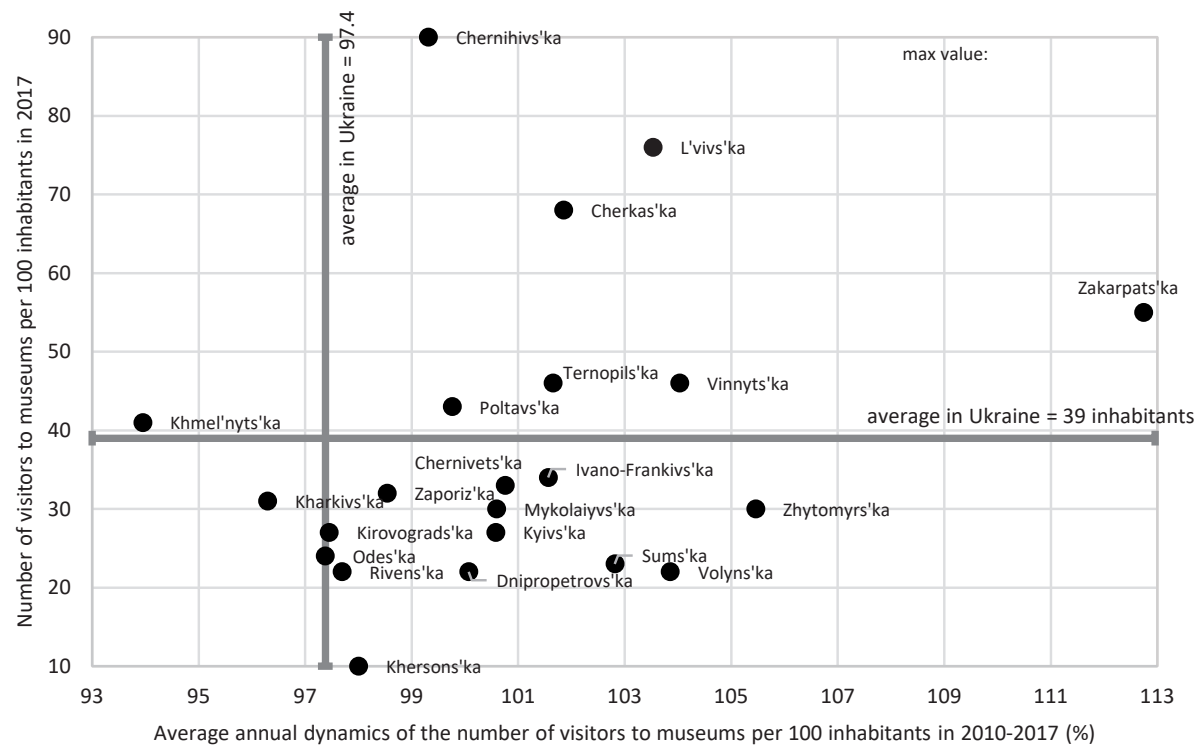

Figure 3. Number of museum visitors of Ukrainian oblasts in 2010-2017

Source: authors' own elaboration based on the data provided by the State Statistics Service of Ukraine http://ukrstat.gov.ua (accessed: 25.07.2019).

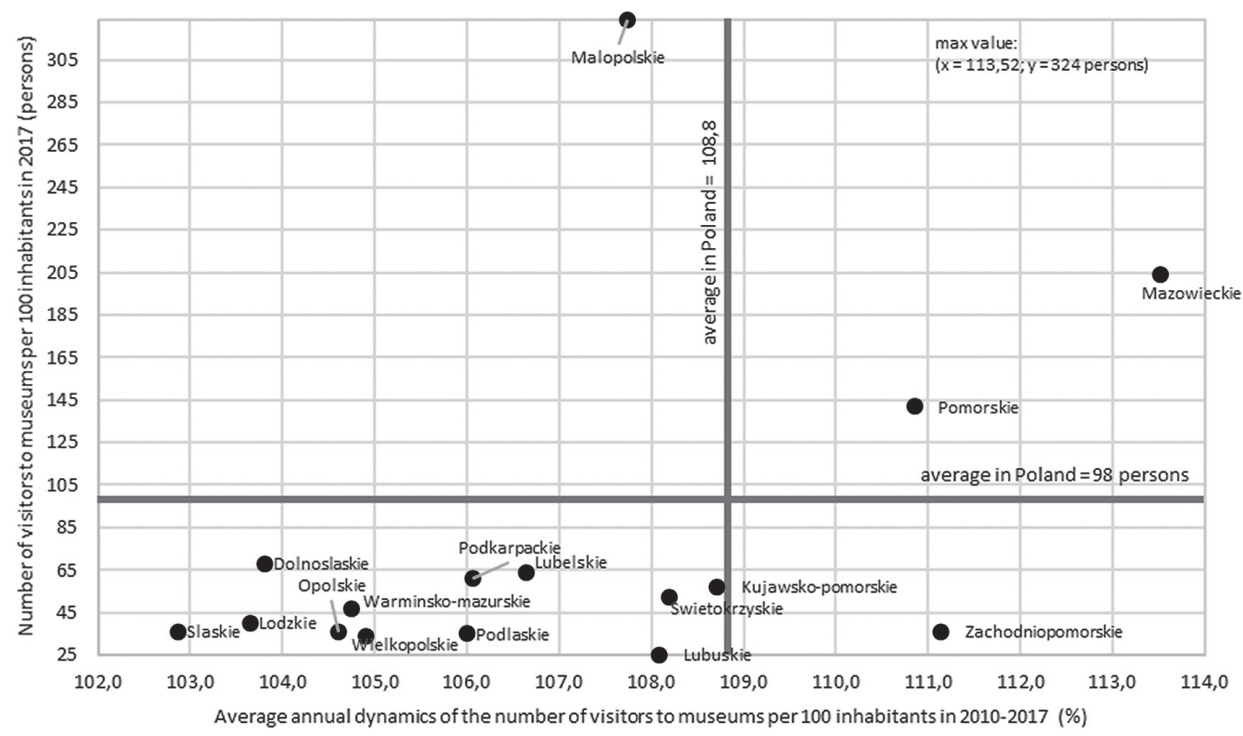

Figure 4. Number of museum visitors in Polish voivodships in 2010-2017

Source: own calculation based on the data provided by the Local Data Bank of Poland http://bdl.stat.gov .pl (accessed: 25.07.2019). 
In 2017, the greatest number of museum visitors in Poland per 100 inhabitants was observed in the following regions: Malopolskie (324), Mazowieckie (204), and Pomorskie (142). At the other end of the scale were the Lubuskie (25), Wielkopolskie (34), Podlaskie (35), Opolskie (36), Slaskie (36) and Zachodniopomorskie (36) voivodships. In addition, there is a significant gap between the minimum and maximum number of museum visitors in Poland. The ratio between the highest number of visitors in Malopolskie voivodship (324 persons) and the smallest in Lubuskie voivodship (25 persons) is a factor of 13 times.

\section{Data and methods}

Methodologically, this research is based on statistical and dynamics methods used in synthetic analysis, which characterize the level of cultural infrastructure development in Ukraine and Poland. The synthetic index is determined using Perkal's synthetic ratio method, also known in the literature as Z-Scores. Perkal's method in this research is used to order the analyzed spatial units on the scale of the level of development measured by a synthetic ratio, including the values of the original indicators that describe the cultural infrastructure development of regions. Data for this analysis are from Polish and Ukrainian public statistics. The time range for assessing the cultural component of social infrastructure covers 2010-2017. The maps were created using the MapInfo Professional software.

The methodological approach of assessing the influence of cultural infrastructure on regional development is presented in Fig. 5.

To begin with, the basis for the dimensional comparative analysis is the choice of variables (statistical indicators) describing the subject of the study. The determination of statistical indicators that characterize the state of the cultural infrastructure of the regions is one of the first and, at the same time, most important and challenging stages of dimensional analysis. The reliability of the final research results depends on the quality of the variables and the accuracy of the decisions based on them.

The first step was to determine the list of statistical indicators that reflect the state of development of cultural infrastructure in Polish and Ukrainian regions. In this research, public statistics were used as the source of data. A large dataset was collected from the website of State Statistics Service of Ukraine (http://ukrstat.gov.ua) and the Local Data Bank of Poland (http://bdl.stat.gov.pl).

The next step was to identify variables that, according to this survey, do not differ from each other or differ significantly. The variables, which are characterized by a low level of differentiation, and those whose coefficient of variation does not exceed 5\%, are eliminated. The elimination of variables is calculated by using the coefficient of variation as follows: 
Alona Revko, Mykola Butko, Olha Popelo

$$
V_{j}=\frac{S_{j}}{\bar{x}_{j}}
$$

where $S_{j}$ - standard deviation of the $\mathrm{j}$-th variable;

$\bar{x}_{j}$ - arithmetic mean of the $\mathrm{j}$-th variable.

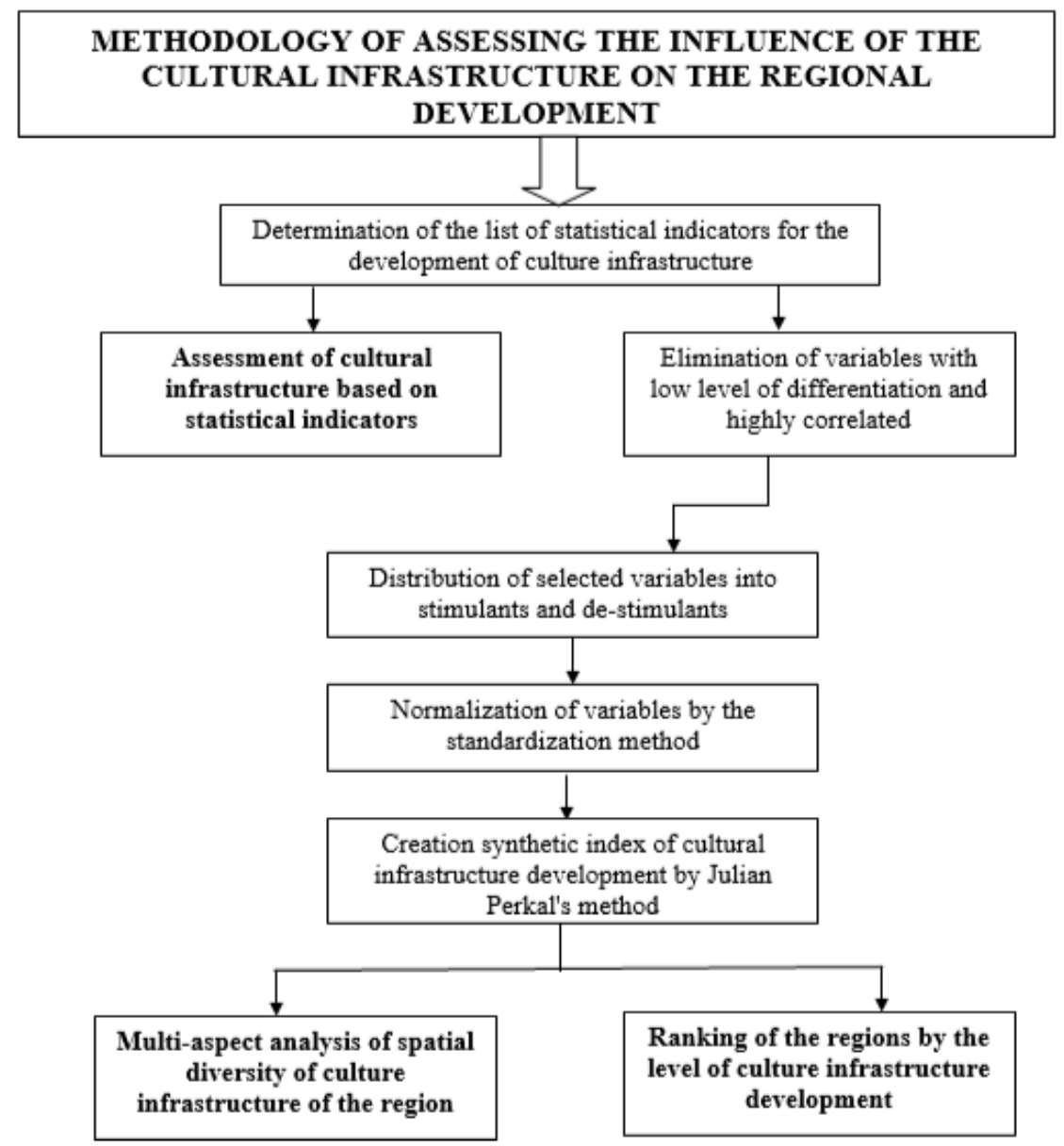

Figure 5. Research framework and methodology

Source: own study based on (Analiza Zróżnicowania 2018, p. 149).

It is important to bear in mind that the variables selected for analysis should not be highly correlated with each other. This can lead to the duplication of information about the object being studied, which can lead to incorrect conclusions. A correlation coefficient above $r=75 \%$ means that the indicator will be eliminated. 
The next stage is to normalize the variables for the regions by standardizing their values. Depending on the influence of these variables on regional development, variable stimulants and de-stimulants are identified.

Standardization is carried out according to the following formula: for stimulants

$$
z_{i j}=\frac{\left(x_{i j}-\bar{x}_{j}\right)}{S_{j}}(j=1,2, \ldots, n)
$$

for de-stimulants

$$
z_{i j}=\frac{\left(\bar{x}_{j}-x_{i j}\right)}{S_{j}}(j=1,2, \ldots, n)
$$

where:

$z_{i j}$ - the standardized value of the $\mathrm{j}$-th variable;

$x_{i j}$ - value of the $\mathrm{j}$-th variable for the region before standardization;

$\bar{X}_{\mathrm{j}}$ - arithmetic mean of the $\mathrm{j}$-th variable;

$S_{j}$ - standard deviation of the $\mathrm{j}$-th variable.

Applying the above formulas will lead to the fact that the range of normalized variables will be identical, which will determine the synthetic index of the regional development of cultural infrastructure.

After using the above formulas, it is possible to create a synthetic index based on the normalized variables. One can also give a graphical representation on the Polish and Ukrainian maps and determine the level of cultural infrastructure development in Polish and Ukrainian regions (16 Polish voivodships and 22 Ukrainian oblasts). Determining the synthetic index is carried out using Perkal's method of linear ordering, by grouping multidimensional objects according to the synthetic criterion, which is a function of the normalized diagnostic variables. The synthetic ratio method makes it possible to provide a linear arrangement of the Polish and Ukrainian regions by describing the values of indicators that characterize cultural infrastructure development using particular social and economic characteristics to show the level of development. The synthetic indicator is calculated by the formula:

$$
W_{i}=\frac{1}{p} \sum_{j=1}^{p} Z_{i j}
$$

where:

$W_{i}$ - synthetic indicator;

$i$ - region;

$p$ - number of considered functions;

$z_{i j}$ - the standardized value of the $\mathrm{j}$-th variable. 
Based on the synthetic indicator, the grouping of the Polish and Ukrainian regions was carried out according to the level of cultural infrastructure development - from the most attractive to the least attractive. In the case of standardizing the variables, the synthetic indicator usually ranges from -3 to 3 . Regions characterized by a high level of development have a synthetic indicator above 0 within the study period, the average level is close to 0 , while regions with a low level have a value below 0 .

Finally, based on Perkal's method, the Polish and Ukrainian regions were ranked and divided into groups with different levels of cultural infrastructure development. As a result, a ranking was created by putting regions in descending order according to the value of the synthetic index. Four groups were identified:

Group A - region-leaders, in which there is the highest level of cultural infrastructure development

$$
\mathrm{W}_{\mathrm{i}} \geq \bar{W}+\mathrm{S}_{(\mathrm{W})}
$$

Group B - leading regions, in which there is a high level of cultural infrastructure development

$$
\bar{W}+\mathrm{S}_{(\mathrm{W})}>\mathrm{Wi} \geq \bar{W}
$$

Group C - peripheral regions, in which there is an average level of cultural infrastructure development

$$
\bar{W}>\mathrm{Wi} \geq \bar{W}-\mathrm{S}_{(\mathrm{W})}
$$

Group D - regions-outsiders, in which there is a low level of cultural infrastructure development

$$
\mathrm{W}_{\mathrm{i}} \geq \bar{W}-\mathrm{S}_{(\mathrm{W})}
$$

where:

$\mathrm{W}_{\mathrm{i}}$ - synthetic index for a particular region;

$\bar{W}$ - the arithmetic mean value of the synthetic index of the region;

$\mathrm{S}_{(\mathrm{W})}-$ standard deviation of the synthetic index of the region. 


\section{Synthetic analysis of the diversification of Polish and Ukrainian regions in terms of cultural infrastructure development}

The first step in the analysis was to identify the variables that describe the object of the research. We have focused on a system of statistical indicators of cultural infrastructure development that includes:

K1. Number of libraries per 100,000 people.

K2. Number of readers per 100 inhabitants.

K3. Library fund per 100 inhabitants, copies.

K4. Number of clubs and sections per 100,000 people.

K5. Number of places in clubs per 100 inhabitants.

K6. Number of museums.

K7. Number of museum visitors per 100 inhabitants.

K8. Number of theaters.

K9. Number of seats in theaters per 10,000 people.

K10. Number of spectators at theater performances per 100 inhabitants.

K11. Number of concert organizations.

K12.Number of visits to concert organizations per 100 inhabitants.

K13. Number of art schools.

K14. Number of students of art schools.

K15. Number of cinemas.

K16. Number of seats in the cinemas per 100 inhabitants.

K17. Number of sports schools.

K18. Number of students of sports schools.

K19. Number of sports facilities per 100,000 people.

The research is based on indicators of cultural infrastructure of 16 Polish voivodships and 22 Ukrainian oblasts.

According to the adopted methodology for determining the synthetic index, the next stage of the analysis is the selection of appropriate variables that will be used in the further part of the study. It is important to note that due to lack of data in Polish public statistics about the number of places in clubs per 100 inhabitants (K5) and the number of sports facilities per 100,000 people (K19), these indicators are not included in the synthetic analysis for Poland. The analysis of cultural infrastructure allows us to identify the variables that are characterized by the lowest level of differentiation and those whose coefficient of variation does not exceed $5 \%$ are eliminated. In this research the coefficient of variation was never less than $5 \%$.

It is necessary to eliminate variables that are characterized by a high coefficient of variation (exceeding 75\%). Tables 3 and 4 present correlation matrices, which are the result of the analysis of the correlation of variables within Ukrainian and Polish regions. 
The analysis of the correlation of variables of cultural infrastructure in Ukraine allows for the elimination of the following indicators from further analysis: K1. Number of libraries per 100,000 people (correlated to the degree of excessive variables K4 and K5); K5. Number of places in clubs per 100 inhabitants (correlated to the degree of excessive variables K1 and K4); K7. Number of visitors to museums per 100 inhabitants (correlated to the degree of excessive variable K12); K13. Number of art schools (correlated to the degree of excessive variables K8, K14, K17, and K18); K14. Number of students of art schools (correlated to the degree of excessive variables K8, K13, K17, and K18); K17 Number of sports schools (correlated to the degree of excessive variables $\mathrm{K} 8, \mathrm{~K} 13, \mathrm{~K} 14$, and K18); K18. Number of students of sports schools (correlated to the degree of excessive variables K8, K13, K14, and K17).

Similarly, the analysis of the correlation of variables of cultural infrastructure development in Poland allows for the elimination of the following indicators from further analysis: K6. Number of museums (correlated to the degree of excessive variables K2, K7, K8, K13, K14, K15, K17, and K18); K7. Number of museum visitors per 100 inhabitants (correlated to the degree of excessive variables K2, K6, and K14); K11. Number of concert organizations (correlated to the degree of excessive variables K8, K15, and K16); K13. Number of art schools (correlated to the degree of excessive variables K6, $\mathrm{K} 8, \mathrm{~K} 14, \mathrm{~K} 15, \mathrm{~K} 17$, and K18); K14. Number of students of art schools (correlated to the degree of excessive variables K2, K7, K7, K13, K15, K17, and K18); K15. Number of cinemas (correlated to the degree of excessive variables K6, K8, K11, K13, K14, K17, and K18); K18. Number of students of sports schools (correlated to the degree of excessive variables $\mathrm{K} 6, \mathrm{~K} 8, \mathrm{~K} 13, \mathrm{~K} 14, \mathrm{~K} 15$, and $\mathrm{K} 17)$.

Table 3. The level of correlation between variables of cultural infrastructure in Ukraine

\begin{tabular}{|c|c|c|c|c|c|c|c|c|c|}
\hline K & 1 & K2 & 3 & 44 & K5 & K6 & K7 & K8 & K9 \\
\hline K1 & O० & 0 & 04 & 26 & 0.8814 & 0.3700 & 39 & -0.6422 & -0.6069 \\
\hline $\mathrm{K} 2$ & & & & & 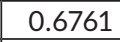 & & & & \\
\hline K3 & & & & & & & & & \\
\hline K4 & & & & & & & & & \\
\hline K5 & & & & & & & & & \\
\hline K6 & & & & & & & & & -0.2301 \\
\hline K7 & & 0 & 0 & 0.3 & 0.3 & 64 & & 73 & 306 \\
\hline $\mathrm{K} 8$ & & & & & & & & & 90 \\
\hline K9 & & & & & 59 & & & & 000 \\
\hline K10 & .1 & 47 & 99 & 35 & -0.2 & & & & .6421 \\
\hline K11 & 0.0 & -0. & 62 & 59 & -0.2069 & & & & .2620 \\
\hline K12 & 8 & & 176 & 4 & 0.4802 & 894 & & -0.0802 & -0.0538 \\
\hline$K$ & 1 & 55 & 77 & 54 & 87 & & & 191 & .5296 \\
\hline K14 & 0 & 79 & 31 & 14 & $\mid-0$ & & & 94 & .4138 \\
\hline K15 & 0.3023 & & 605 & 58 & 0.2315 & & & 362 & -0.0215 \\
\hline K1 & 1924 & & & 8 & 88 & & & 283 & -0.1166 \\
\hline K1 & 5 & & & 63 & 30 & & & & 150 \\
\hline $\mathrm{K} 1$ & 0.6772 & -0.6 & -0.1 & -0.6 & -0.5997 & & & 0.8220 & .5162 \\
\hline K19 & 0.2865 & 0.2496 & 0.3079 & 0.3379 & 0.3411 & -0.0313 & -0.2576 & -0.2763 & -0.2807 \\
\hline
\end{tabular}


Methodology for Assessing the Influence of Cultural Infrastructure...

\begin{tabular}{|l|r|r|r|r|r|r|r|r|r|}
\hline K & \multicolumn{1}{|c|}{ K11 } & \multicolumn{1}{|c|}{ K12 } & \multicolumn{1}{|c|}{ K13 } & \multicolumn{1}{|c|}{ 14 } & \multicolumn{1}{c|}{ K15 } & \multicolumn{1}{c|}{ K16 } & \multicolumn{1}{|c|}{ K17 } & \multicolumn{1}{|c|}{ K18 } & \multicolumn{1}{|c|}{ K19 } \\
\hline K1 & -0.0359 & 0.5138 & -0.5501 & -0.4540 & 0.3023 & 0.1924 & -0.5885 & -0.6772 & 0.2865 \\
\hline K2 & -0.0816 & 0.3739 & -0.6365 & -0.4679 & 0.0534 & 0.1087 & -0.5454 & -0.6828 & 0.2496 \\
\hline K3 & -0.0462 & 0.4176 & -0.2877 & -0.2381 & 0.2605 & 0.3505 & -0.0123 & -0.1278 & 0.3079 \\
\hline K4 & -0.0008 & 0.5104 & -0.5254 & -0.4114 & 0.2558 & 0.1808 & -0.5363 & -0.6357 & 0.3379 \\
\hline K5 & -0.2069 & 0.4802 & -0.5587 & -0.4771 & 0.2315 & 0.3088 & -0.5130 & -0.5997 & 0.3411 \\
\hline K6 & 0.1994 & 0.2894 & 0.2271 & 0.2155 & 0.4226 & 0.1576 & 0.2383 & 0.2548 & -0.0313 \\
\hline K7 & 0.4029 & 0.7847 & 0.0559 & 0.1229 & 0.2640 & 0.1747 & 0.0375 & -0.0866 & -0.2576 \\
\hline K8 & 0.5457 & -0.0802 & 0.8491 & 0.8294 & -0.0362 & -0.2283 & 0.8556 & 0.8220 & -0.2763 \\
\hline K9 & 0.2620 & -0.0538 & 0.5296 & 0.4138 & -0.0215 & -0.1166 & 0.5150 & 0.5162 & -0.2807 \\
\hline K10 & 0.2528 & 0.1289 & 0.2001 & 0.1614 & 0.0708 & -0.0450 & 0.3709 & 0.2826 & 0.2241 \\
\hline K11 & 1.0000 & 0.3892 & 0.5651 & 0.6503 & 0.0988 & -0.2317 & 0.5322 & 0.3707 & -0.2779 \\
\hline K12 & 0.3892 & 1.0000 & -0.1518 & -0.1269 & 0.2271 & 0.3021 & -0.1477 & -0.2842 & -0.0095 \\
\hline K13 & 0.5651 & -0.1518 & 1.0000 & 0.8781 & 0.1889 & -0.0541 & 0.7664 & 0.8359 & -0.4212 \\
\hline K14 & 0.6503 & -0.1269 & 0.8781 & 1.0000 & 0.0022 & -0.3080 & 0.7899 & 0.7707 & -0.4731 \\
\hline K15 & 0.0988 & 0.2271 & 0.1889 & 0.0022 & 1.0000 & 0.6886 & -0.0387 & 0.1167 & -0.1102 \\
\hline K16 & -0.2317 & 0.3021 & -0.0541 & -0.3080 & 0.6886 & 1.0000 & -0.1483 & -0.0301 & 0.1057 \\
\hline K17 & 0.5322 & -0.1477 & 0.7664 & 0.7899 & -0.0387 & -0.1483 & 1.0000 & 0.8886 & -0.1861 \\
\hline K18 & 0.3707 & -0.2841 & 0.8359 & 0.7707 & 0.1167 & -0.0301 & 0.8886 & 1.0000 & -0.2510 \\
\hline K19 & -0.2779 & -0.0095 & -0.4211 & -0.4731 & -0.1102 & 0.1057 & -0.1861 & -0.2510 & 1.0000 \\
\hline
\end{tabular}

Source: own calculation.

Table 4. The level of correlation between variables of cultural infrastructure in Poland

\begin{tabular}{|c|c|c|c|c|c|c|c|c|c|}
\hline K & K1 & K2 & K3 & K4 & K6 & K7 & K8 & K9 & K10 \\
\hline K1 & 1.0000 & 0.0587 & 0.0807 & 0.6363 & -0.2581 & -0.1121 & -0.4414 & -0.6699 & -0.6837 \\
\hline K2 & 0586 & 1.0000 & 0.5259 & 0.4778 & 0.8175 & 0.7869 & 0.6395 & 0.0919 & 0.3351 \\
\hline K3 & 0.0807 & 0.5259 & 1.0000 & 0.1381 & 0.6472 & 0.5266 & 0.7017 & -0.0514 & 0.3386 \\
\hline K4 & 0.6363 & 0.4778 & 0.1381 & 1.0000 & 0.1920 & 0.2246 & -0.0454 & -0.1699 & -0.3133 \\
\hline $\mathrm{K} 6$ & .2580 & 0.8175 & 0.6472 & 0.1920 & 1.0000 & 0.8107 & 0.8762 & 0.2358 & 0.5389 \\
\hline K7 & .1120 & 0.7869 & 0.5267 & 0.2246 & 0.8107 & 1.0000 & 0.6108 & 0.2992 & 0.5105 \\
\hline $\mathrm{K} 8$ & -0.4414 & 0.6395 & 0.7017 & -0.0455 & 0.8762 & 0.6108 & 1.0000 & 0.3643 & 0.7429 \\
\hline K9 & -0.6699 & 0.0919 & -0.0514 & -0.1699 & 0.2358 & 0.2992 & 0.3643 & 1.0000 & 0.7098 \\
\hline K10 & -0.6837 & 0.3351 & 0.3386 & -0.3133 & 0.5389 & 0.5105 & 0.7429 & 0.7098 & 1.0000 \\
\hline K11 & -0.5665 & 0.5107 & 0.3231 & -0.0817 & 0.7389 & 0.3922 & 0.8443 & 0.4996 & 0.7007 \\
\hline K12 & -0.2734 & 0.0387 & -0.3963 & -0.0851 & -0.1314 & -0.0863 & 0.0127 & 0.4179 & 0.3043 \\
\hline K13 & -0.1066 & 0.7186 & 0.7161 & 0.2007 & 0.9044 & 0.6889 & 0.8779 & 0.0803 & 0.4703 \\
\hline K14 & -0.0589 & 0.8342 & 0.6048 & 0.2364 & 0.8856 & 0.7806 & 0.7469 & 0.0184 & 0.3442 \\
\hline K15 & -0.2268 & 0.6749 & 0.6443 & 0.1231 & 0.8723 & 0.5206 & 0.9177 & 0.1100 & 0.5243 \\
\hline K16 & -0.4862 & 0.3747 & 0.1954 & 0.1145 & 0.6529 & 0.3219 & 0.6344 & 0.3471 & 0.4625 \\
\hline K17 & -0.0931 & 0.6547 & 0.5028 & 0.2504 & 0.8105 & 0.4463 & 0.7298 & -0.0393 & 0.2479 \\
\hline K18 & -0.1925 & 0.6796 & 0.5818 & 0.1292 & 0.8519 & 0.5203 & 0.8570 & 0.0502 & 0.4149 \\
\hline K & K11 & K12 & K13 & K14 & K15 & K16 & K17 & K18 & \\
\hline $\mathrm{K} 1$ & -0.5665 & -0.2734 & -0.1066 & -0.0589 & -0.2268 & -0.4862 & -0.0931 & -0.1925 & \\
\hline $\mathrm{K} 2$ & 0.5107 & 0.0387 & 0.7186 & 0.8342 & 0.6749 & 0.3747 & 0.6547 & 0.6796 & \\
\hline K3 & 0.3231 & -0.3963 & 0.7161 & 0.6048 & 0.6443 & 0.1954 & 0.5028 & 0.5818 & \\
\hline K4 & -0.0817 & -0.0851 & 0.2007 & 0.2364 & 0.1231 & 0.1145 & 0.2504 & 0.1292 & \\
\hline K6 & 0.7389 & -0.1314 & 0.9044 & 0.8856 & 0.8723 & 0.6529 & 0.8105 & 0.8519 & \\
\hline K7 & 0.3922 & -0.0863 & 0.6889 & 0.7806 & 0.5206 & 0.3219 & 0.4463 & 0.5203 & \\
\hline
\end{tabular}


Table 4. (continued)

\begin{tabular}{|l|c|r|r|r|r|r|r|c|}
\hline \multicolumn{1}{|c|}{ K } & K11 & \multicolumn{1}{c|}{ K12 } & \multicolumn{1}{c|}{ K13 } & \multicolumn{1}{c|}{ K14 } & \multicolumn{1}{c|}{ K15 } & \multicolumn{1}{c|}{ K16 } & \multicolumn{1}{c|}{ K17 } & K18 \\
\hline K8 & 0.8442 & 0.0127 & 0.8779 & 0.7469 & 0.9177 & 0.6344 & 0.7298 & 0.8570 \\
\hline K9 & 0.4997 & 0.4179 & 0.0803 & 0.0184 & 0.1100 & 0.3471 & -0.0393 & 0.0501 \\
\hline K10 & 0.7007 & 0.3043 & 0.4703 & 0.3442 & 0.5243 & 0.4625 & 0.2479 & 0.4149 \\
\hline K11 & 1.0000 & 0.3499 & 0.6469 & 0.5398 & 0.8169 & 0.7623 & 0.6664 & 0.7382 \\
\hline K12 & 0.3499 & 1.0000 & -0.1507 & -0.0914 & 0.0297 & 0.2677 & -0.0237 & 0.0101 \\
\hline K13 & 0.6469 & -0.1507 & 1.0000 & 0.9180 & 0.9244 & 0.5723 & 0.8682 & 0.9364 \\
\hline K14 & 0.5398 & -0.0914 & 0.9180 & 1.0000 & 0.7921 & 0.5164 & 0.8602 & 0.8949 \\
\hline K15 & 0.8169 & 0.0297 & 0.9244 & 0.7921 & 1.0000 & 0.6811 & 0.8638 & 0.9308 \\
\hline K16 & 0.7623 & 0.2677 & 0.5723 & 0.5164 & 0.6811 & 1.0000 & 0.7375 & 0.6936 \\
\hline K17 & 0.6664 & -0.0237 & 0.8682 & 0.8602 & 0.8638 & 0.7375 & 1.0000 & 0.9631 \\
\hline K18 & 0.7382 & 0.0101 & 0.9364 & 0.8949 & 0.9308 & 0.6936 & 0.9631 & 1.0000 \\
\hline
\end{tabular}

Source: own calculation.

Finally, the values of the index, rank, and group of each Polish voivodship are presented in Table 5, while the spatial differentiation of the value of the synthetic indicator is presented in Fig. 6. The highest value of the index characterizes the region with the highest level of culture infrastructure development, the lowest value - the region with the lowest level.

Table 5. Ranking of Polish regions according to the level of cultural infrastructure development in 2017

\begin{tabular}{|l|c|c|c|}
\hline \multicolumn{1}{|c|}{ Region name } & Rank & Perkal's index & Group \\
\hline Mazowieckie & 1 & 1.1027 & A \\
\hline Dolnoslaskie & 2 & 0.8364 & A \\
\hline Malopolskie & 3 & 0.7670 & A \\
\hline Slaskie & 4 & 0.3291 & B \\
\hline Pomorskie & 5 & 0.3097 & B \\
\hline Wielkopolskie & 6 & 0.0177 & B \\
\hline Lubelskie & 7 & -0.0480 & $\mathrm{C}$ \\
\hline Opolskie & 8 & -0.1527 & $\mathrm{C}$ \\
\hline Podkarpackie & 9 & -0.1576 & $\mathrm{C}$ \\
\hline Zachodniopomorskie & 10 & -0.2670 & $\mathrm{C}$ \\
\hline Lubuskie & 11 & -0.2686 & $\mathrm{C}$ \\
\hline Kujawsko-pomorskie & 12 & -0.2733 & $\mathrm{C}$ \\
\hline Lodzkie & 13 & -0.3633 & $\mathrm{C}$ \\
\hline Warminsko-mazurskie & 14 & -0.5169 & $\mathrm{C}$ \\
\hline Podlaskie & 15 & -0.5251 & $\mathrm{D}$ \\
\hline Swietokrzyskie & 16 & -0.7900 & $\mathrm{D}$ \\
\hline
\end{tabular}

Source: author's own elaboration based on data provided by the Local Data Bank of Poland http://bdl .stat.gov.pl (accessed: 25.07.2019).

Group A, with the highest level of cultural infrastructure development, consists of 3 voivodships, among which the highest level of the index was recorded in Mazowieckie, Dolnoslaskie, and Malopolskie. Group B also consists of 3 voivodships, which have a high level of development: Slaskie, Pomorskie, and Wielkopolskie. Due to their medi- 
um level of development, eight voivodships (the biggest one in Poland) were classified into group C. Group D consists of only 2 voivodships with a low level of development: Podlaskie and Swietokrzyskie. These voivodships have low values of all indicators: low number of sports schools and concert organizations.

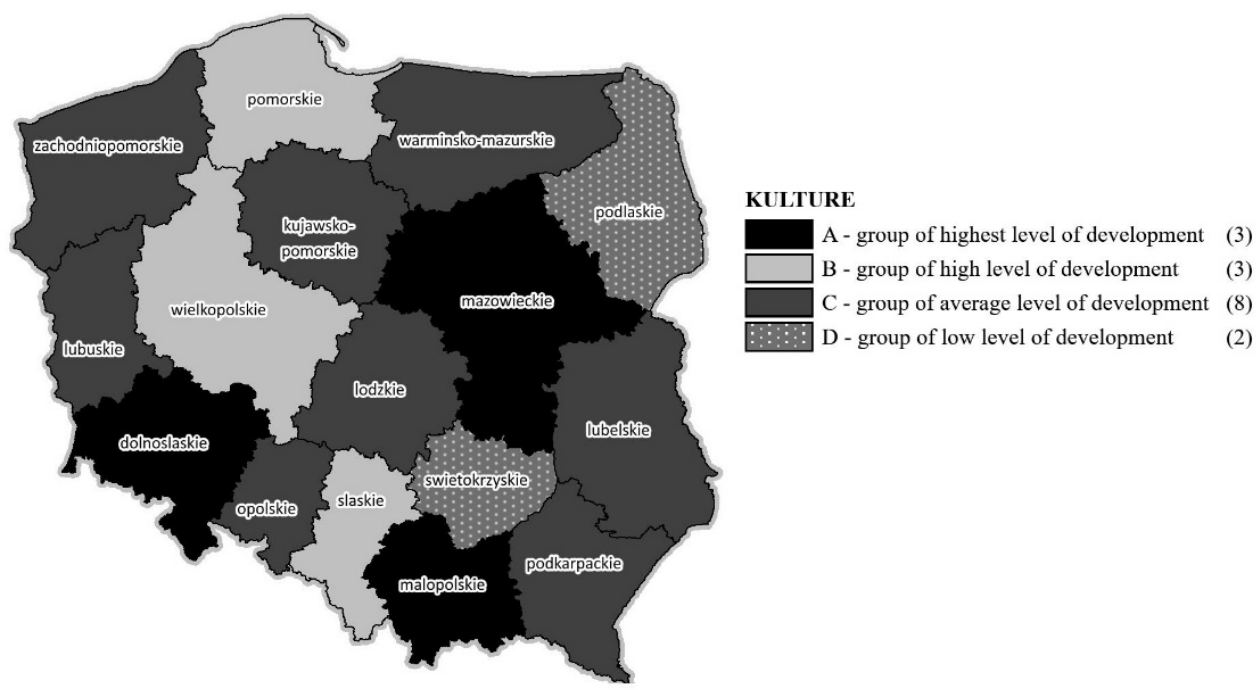

Figure 6. Map of regional differentiation of the index of cultural infrastructure development in Poland in 2017

Source: authors' own elaboration based on data provided by the Local Data Bank of Poland http://bdl.st at.gov.pl (accessed: 25.07.2019).

The synthetic index of cultural infrastructure development in Ukraine is presented in Table 6, and the spatial distribution is in Fig. 7.

Table 6. Ranking of Ukrainian regions according to the level of cultural infrastructure development in 2017

\begin{tabular}{|l|c|c|c|}
\hline \multicolumn{1}{|c|}{ Region name } & Rank & Perkal's index & Group \\
\hline Chernihivs'ka & 1 & 1.0134 & $\mathrm{~A}$ \\
\hline L'vivs'ka & 2 & 0.7602 & $\mathrm{~A}$ \\
\hline Khmel'nyts'ka & 3 & 0.5876 & $\mathrm{~A}$ \\
\hline Vinnyts'ka & 4 & 0.3513 & $\mathrm{~B}$ \\
\hline Ternopils'ka & 5 & 0.3503 & $\mathrm{~B}$ \\
\hline Kharkivs'ka & 6 & 0.2141 & $\mathrm{~B}$ \\
\hline Ivano-Frankivs'ka & 7 & 0.1545 & $\mathrm{~B}$ \\
\hline Kirovograds'ka & 8 & 0.1064 & $\mathrm{~B}$ \\
\hline Mykolayivs'ka & 9 & 0.0065 & $\mathrm{~B}$ \\
\hline Dnipropetrovs'ka & 10 & -0.0337 & $\mathrm{C}$ \\
\hline Zhytomyrs'ka & 11 & -0.0652 & $\mathrm{C}$ \\
\hline Odes'ka & 12 & -0.0709 & $\mathrm{C}$ \\
\hline
\end{tabular}


Table 6. (continued)

\begin{tabular}{|l|c|c|c|}
\hline \multicolumn{1}{|c|}{ Region name } & Rank & Perkal's index & Group \\
\hline Cherkas'ka & 13 & -0.0866 & C \\
\hline Volyns'ka & 14 & -0.1337 & C \\
\hline Poltavs'ka & 15 & -0.1696 & C \\
\hline Chernivets'ka & 16 & -0.2114 & C \\
\hline Rivens'ka & 17 & -0.2421 & C \\
\hline Khersons'ka & 18 & -0.2605 & C \\
\hline Sums'ka & 19 & -0.2819 & C \\
\hline Zaporiz'ka & 20 & -0.4815 & D \\
\hline Zakarpats'ka & 21 & -0.6698 & D \\
\hline Kyivs'ka & 22 & -0.8374 & D \\
\hline
\end{tabular}

Source: authors' own elaboration based on data provided by the State Statistics Service of Ukraine http://ukrstat.gov.ua (accessed: 25.07.2019).

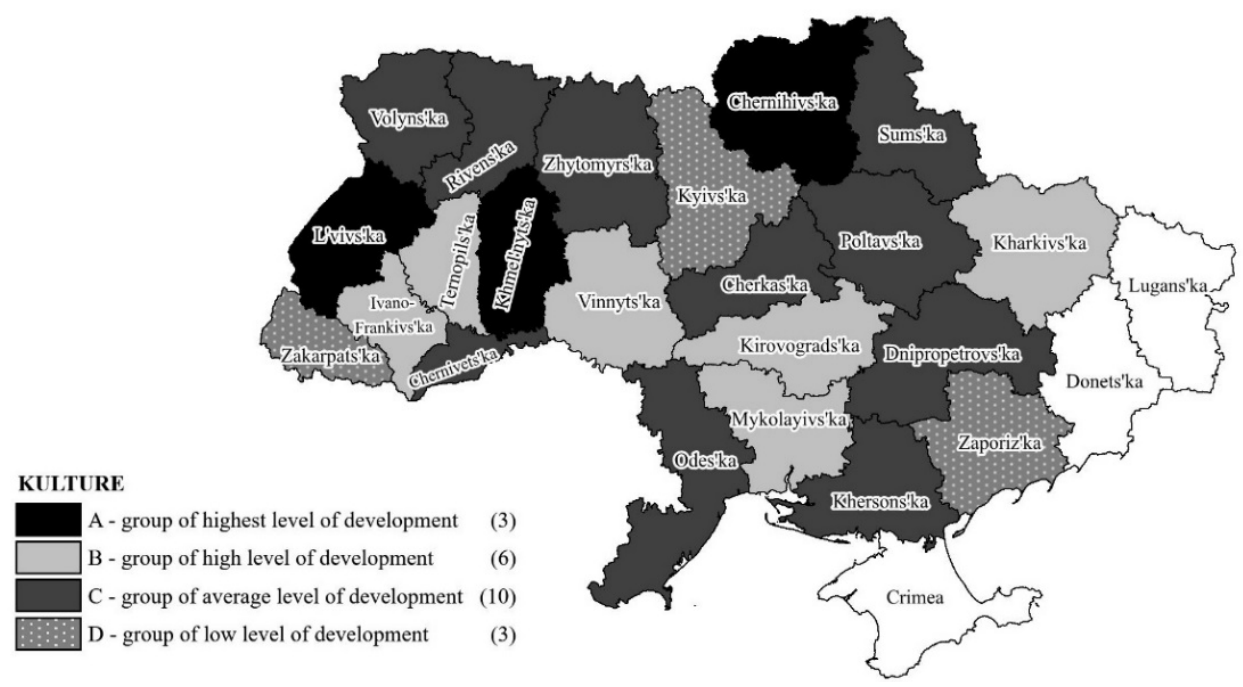

Figure 7. Map of regional differentiation of the index of cultural infrastructure development in Ukraine in 2017

Source: authors' own elaboration based on data provided by the State Statistics Service of Ukraine http://ukrstat.gov.ua (accessed: 25.07.2019).

Subsequently, the classification of Ukrainian regions according to the value of Perkal's index shows that the leader in the ranking of cultural infrastructure development in 2017 was Chernihivs'ka oblast, while last place was occupied by Kyivs'ka oblast (Fig. 7).

At the other end of the scale, group A, with the highest level of cultural infrastructure development was composed of the following oblasts: Chernihivs'ka, L'vivs'ka and Khmel'nyts'ka. A slightly less favorable situation was registered in oblasts belonging to group B, with a high level of cultural development, including Vinnyts'ka, Ternopils'ka, Kharkivs'ka, Ivano-Frankivs'ka, Kirovograds'ka, and Mykolayivs'ka. 
Group C was the biggest, which included ten oblasts with a medium level of cultural infrastructure development. The weakest oblasts are in group D, and include Zaporiz'ka, Zakarpats'ka, and Kyivs'ka.

\section{Discussions and conclusions}

It is important to bear in mind that the regional cultural infrastructure is a complex system of relationships among individuals and public, private, for-profit, and not-forprofit institutions. This system provides for the transmission of culture from creators to audiences through museums, libraries, theaters, concert organizations, cinemas, and art and sports schools.

For that reason, this article analyzed the regional differentiation in cultural infrastructure development in Poland and Ukraine. The result of the study show a negative trend in the number of cultural infrastructure institutions in Ukraine between 2005 and 2017. In 2017 , the number of libraries decreased by $20 \%$ in comparison with 2005 , the number of theaters declined by $16 \%$, the number art schools - by $12 \%$, and clubs - by $11 \%$.

Conversely, the change in the number of Polish cultural institutions between 2005 and 2017 had a positive trend. There was an increase in the number of almost all cultural infrastructure institutions.

The vast majority of people in Ukrainian regions don't have access to institutions of cultural infrastructure. One can thus conclude that the regional differentiation in cultural infrastructure has a measurable effect on cultural consumption behaviors in the respective region, even if it is not evident in all cultural realms to the same degree.

Classification of regions according to the value of Perkal's index shows that three oblasts in Ukraine (Chernihivs'ka, L'vivs'ka, and Khmel'nyts'ka) and three voivodships in Poland (Mazowieckie, Dolnoslaskie, and Malopolskie) are the leaders in the ranking of cultural infrastructure development. It is worth noting that Ukraine exhibits an uneven distribution of cultural infrastructure. As follows from the analysis, Ukraine and Poland have gaps in cultural infrastructure development, and educational and cultural resources and opportunities.

The underlying barriers to access to cultural infrastructure in Ukraine are inadequate funding, disability, geographic remoteness, and disparities in education and material living conditions. To enable fuller participation in the cultural life of the nation and to foster of cultural infrastructure development of the regions, the following must take place:

- create new cultural institutions and improve the accessibility and quality of existing ones;

- develop a system of public cultural services to meet the needs of different customer groups and develop localized service system;

- supporting entrepreneurship in the cultural and creative industries, improving the economic importance of culture; 
- attract investments of regional and international significance to the sphere of culture;

- support the development of competences and skills of employees who are engaged in the cultural infrastructure;

- improve the financing system of cultural infrastructure (the effective use of state and local budgets, international funds) and social participation of local communities.

In terms of regional development, communities contribute meaningfully to the cultural infrastructure, forming the cultural ethos of the nation. Public policy should attempt to lower barriers to access and facilitate participation in the development of the cultural infrastructure. Cultural infrastructure and the creative industries are major components of a region's attractiveness and they provide a vision for its economic development and job creation.

\section{References}

Allison Brugg Bawden (2002), Access and the Cultural Infrastructure, Center for Arts and Culture Art., "Culture \& the National Agenda Issue Paper".

Analiza Zróżnicowania Wewnątrzregionalnego Województwa Wielkopolskiego 2017 [Analysis of Intraregional Diversity of the Wielkopolska Region 2017] (2018), Wielkopolskie Regionalne Obserwatorium Terytorialne, Poznań (in Polish).

Bryson, J.R. (2007), Arts, Dance, Cultural Infrastructure, and City Regeneration: Knowledge, Audience Development, Networks, and Conventions, and the Relocation of a Royal Ballet Company from London to Birmingham, "Norsk Geografisk Tidsskrift. Norwegian Journal of Geography”, Vol. 61 (3), pp. 98-110, Oslo. https:// doi.org/10.1080/00291950701553848

Florida, R. (2005). The Flight of the Creative Class. Harper Business, New York. https:// doi.org/10.4324/9780203997673

Gökçe Sanul \& Bas van Heur (2018), Urban Citizenship and Cultural Infrastructures of Common Life in Istanbul City, Vol. 22, pp. 801-819. https://doi.org/10.1080/136 04813.2018.1549854

Kultura w 2017 r. Informacje statystyczne [Culture in 2017. Statistical information] (2018). Główny Urząd Statystyczny, Warszawa (in Polish).

Public Libraries in the United States Survey, (2014), Institute of Museum and Library Services.

Revko, A. (2017), Problemy i infrastruktura społeczna na rynku pracy Ukrainy [Problems and Social Infrastructure in the Labor Market of Ukraine], "Rynek pracy", Vol. 4 (163), pp. 30-36, Warszawa.

Rössel, J., Weingartner, S. (2016), Opportunities for cultural consumption: How is cultural participation in Switzerland shaped by regional cultural infrastructure? "Rationality and Society”, Vol. 28 (4), pp. 363-385. https://doi.org/10.1177/1043463116658872 


\section{Streszczenie}

\section{Metodologia oceny wpływu infrastruktury kulturalnej na rozwój regionalny w Polsce i na Ukrainie}

Celem artykułu jest określenie poziomu zróżnicowania regionu pod względem komponentu kulturowego infrastruktury społecznej, na podstawie zgrupowanych wskaźników statystycznych. W pracy wykorzystano metodę wskaźnika syntetycznego Perkala do scharakteryzowania poziomu rozwoju infrastruktury kulturalnej w regionach ukraińskich i polskich. Analiza przeprowadzona w latach 2010-2017 dotyczyła organizacji kulturalnych, takich jak biblioteki, teatry, instytucje organizujące koncerty, muzea, kina, szkoły artystyczne i sportowe. Wykorzystano regionalne dane statystyczne z Polski i Ukrainy. Stwierdzono, że podstawowymi barierami w dostępie do infrastruktury kulturalnej są niewystarczające fundusze, niepełnosprawność, oddalenie geograficzne, dysproporcje w zakresie edukacji i materialne warunki życia. Określono uwarunkowania modernizacji infrastruktury kulturalnej w regionie.

Słowa kluczowe: infrastruktura społeczna, infrastruktura kulturalna, rozwój człowieka, rozwój regionalny 